\title{
Cultural Angle and Degrees of Transculturation in Multicultural Societies
}

David Caballero Mariscal. Prof. Dr.

\author{
University of Granada \\ Email:davidcaballero@ugr.es \\ Agar Marín Morales, Researcher \\ University of Granada \\ Email: agarmarinmorales@gmail.com
}

Doi:10.5901/mjss.2015.v6n4s3p590

\begin{abstract}
Current Western societies are characterized by cultural diversity. Europe has gradually become a place populated by very diverse groups, due mainly to an influx of immigration. Various adaptation mechanisms have developed in the receiving society, and in turn, in immigrant groups. Due to a variety of factors, including well-embedded social prejudices, stereotypes and cultural distance, there are different expressions of ethnocentrism and degrees of transculturation in multicultural contexts. The main focus of this paper is to establish an original and realistic classification of these social responses, based on systematic observation and direct interaction
\end{abstract}

Keywords: multiculturalism, ethnocentrism, transculturation, adaptation responses

\section{Introduction}

Society today is affected by multiculturalism, due to immigration flows, with progressively more cultural, ethnic and social diversity. This implies new challenges which must be faced, in order to learn and to build a new society open to changes and to social and cultural enrichment.

There are two important responses or mechanisms of adaptation invoked by cultural groups to survive in multicultural contexts. The first is ethnocentrism itself. This response often tends to become disproportionate in many contexts. Nevertheless, it is a normal mechanism, often induced by fear of alterity. Cultural boundaries are usually determined by this factor, because there is an indirect fear losing a group's own identity or rights. This defensive attitude is usually deep-rooted in immigrants, and also in the destination country, resulting ininevitable cultural conflict between the different groups.

\section{The Cultural Angle}

In every social and historical process there are encounters between diverse elements belonging to different traditions. Culture is forged from different causes and circumstances; among them adaptation processes, similar in every people as far as mechanisms and responses are concerned, but divergent and unique in each particular case.

The cultural angle can be considered as the distance between two different cultural collectives. Each arm represents one group, and its own position as far as culture is concerned. Each group has a central identity from its own point of view, and its essence and cosmovision reflect this. We must emphasize that the farther apart two cultures are, the more open the angle is. This distance depends on a number of factors:

- Physical distance

- $\quad$ Little knowledge about the other group

- $\quad$ Lack of contact or mutual interactions

- Deep-rooted prejudices. 


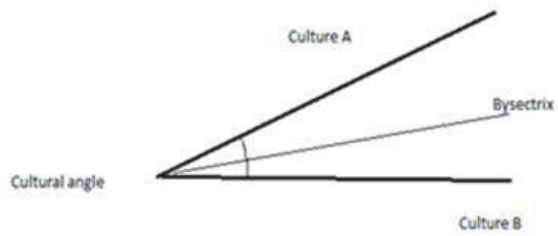

Diagram 1. Cultural angle and bisectors (bysectrix).Self elaboration

This diagram aims to show the relationship between or among cultural groups in a particular context. In the confrontation between different collectives each one exerts an influence on the other(s). Each arm represents one culture, and the angle symbolizes the distance between them. The farther apart or divergent the collectives are, the more open the angle is. On the other hand, the bisector is not only the midpoint toward which both groups should move to develop an understanding and mutual approach, but paradoxically it also represents the boundaries or limits at the meeting of their co-occupation and reciprocal relations. The distance between the two arms and the bisector represents the area of cultural identity. Every group tries to extend its particular area into the territory of the other. This shifts the bisector according to the direct or indirect pressure imposed by the collectives. Regardless, this midpoint is usually nearer the arm of the weaker or smaller group.

Due to both exogenous and endogenous factors, it can prove almost impossible, or rather utopian, to obtain a point halfway between the two perspectives. This area, which could entail a middle perspective between both cultures and that can be considered a genuine bisector, is often diffused. The line of this bisector, and its area of influence, is usually undetectable, because it is normally closer to the stronger group. On the other hand, many collectives develop survival mechanisms that contribute to the maintenance of their original identity. In any case, each group exerts its influence on the other(s), and this implies a heterogeneous new reality as a result of the contact between the different cultures whether they are stronger or weaker.

\section{Transculturation: An Adaptive Strategy}

Encounters between different cultures have generated different mechanisms of resistance. In the case of peoples and cultures that have suffered from cultural imposition processes, this is particularly significant. These reactions, in asymmetric contexts, invoke a variety of responses; on one hand, the survival of different underlying elements belonging to the previous culture, perceived as weak; and on the other hand, the emergence of new cultural manifestations as a result of the interaction between them.

The term transculturation, with all its limits and diversity of interpretations, was initially coined by the writer and thinker Fernando Ortiz, in his book Contrapunteo cubano del tabaco y del azúcar (1940), and it referred to the generation of new cultural elements as a result of the convergence of these processes. Ortiz underscores that the encounter between different cultures or civilizations triggers two important processes: the transmission of elements from one culture to another, and the loss or alienation of many aspects from the former culture. Still, this partial disappearance of the original culture, characterized by an evident asymmetry between the two, for different reasons, is usually followed by the emergence of a new identity based on new cultural phenomena.

Clearly, second and subsequent generations maintain strong holds of both of the previous cultures they come from, to a greater or lesser extent. The resulting culture differs from that of the original peoples, and becomes, in turn, a new different and original reality (Ortiz, 1940, pp. 91-97).

The anthropologist Ortiz observed his own country's society. The diversity and the final result of cultural fusion he saw led him to propose a distinction between the terms acculturation and transculturation. The former is related to passive assimilation. This particular procedure is associated to deculturation or to a loss of cultural elements due to the pressure of the dominant people. There is an asymmetric perception of the two cultures, because one of them is considered more powerful and stronger, and the other weaker, fragile and easy to control or even to dominate. Transculturation, in contrast, can imply a process of survival and the incorporation of features belonging to the subjugated culture; a mixture of elements from both peoples. As a result, a new cultural manifestation emerges, thanks to a neoculturation process (Ortiz, 1940). There are, however, some inaccuracies in the description by Ortiz of these terms. 
Transculturation is often identified and linked to assimilation. Nevertheless, assimilation must be distinguished from the concept of acculturation. Both refer to the process by which cultures and peoples undergo changes through adaptation and due to the pressure to adapt to a new group or society, as in the case of immigration. Acculturation, however, refers to changes in habits, beliefs and behaviors by a group or an individual as they conform to a new culture.

Ángel Rama adapts and assimilates the concept of transculturation to highlight its "cultural plasticity" (p. 208) in that it enables the integration of new with traditional elements. As a result, the dynamic final product is a new reconfiguration of the prior cultural structure, with new characteristics. Muyolema Calle (2007) similarly claims that transculturation can at most be considered a "journey experienced through two different social worlds" (p. 23), and "a space of meditation and cultural translation inside a significance horizon of modernity" (p. 85). This implies an inevitably painful experience. People belonging to the previous culture develop a variety of mechanisms to adjust themselves to the new situation by means of acculturative responses. Berry (1997) refers to different ways of acculturation as a strategy to adapt to new unexpected feelings and psychological impacts: assimilation, inclusion (integration), marginalization and separation. We can consider groups who stay apart from society, belonging just to one culture, as deprived; obviously different from the most influential groups in the receptive country. On the other hand, assimilated individuals suffer from the lack of their origin culture and identity. In both cases, there is a significant identification with only one culture, whether the mainstream or the native culture.

Antonio Cornejo Polar (1994) revisits the concept, aiming to analyze new situations and different contexts. The term is doubtless original and useful, in spite of its limits, although it cannot be extrapolated to every case or situation. This cultural synthesis does not always meet all the requirements of every cultural context. In addition, the transcultural perspective is almost always analyzed and described from a subjective point of view: that of the hegemonic culture. Transculturation is a quick answer to particular adaptation needs and a cultural way to survive in an adverse context. According to Cornejo, transculturation implies a mutilation of identity, although this may be to a greater or lesser extent depending on the circumstances and particular processes. It should be emphasized that there is a "symbiosis of representations" (Mazeau de Fonseca, 2004, p. 200), although a significant part of the beliefs, mores, habits, and important elements belonging to the source culture have yielded to circumstances. In fact, every culture can recognize itself in part of the new blend, mainly because its members have kept a part of the essential code they used to belong to. In any case, a different culture takes shape, and it, in turn, is the means by which a new identity is forged that keeps features and elements of both of the contributing cultures. Even so, Ortiz notes that "this process necessarily implies a lossor alienation of the previous culture; in other words, a partial deculturation and the consequent creation of a new cultural phenomenon" (p. 96).

Today's society is characterized by multiculturalism, interculturality and transculturation. In the meeting of cultures in times of heavy migration, societies have become new forums for change, encounters between different cultural meanings, different values, choices and points of view. This contributes to change and cultural richness, but in turn, new conflictive situations, due to people's priorities, ways of life, choices and behaviors. It is important to note that these phenomena and situations are not only a diachronic process. Most societies today can be considered as multicultural. It is thus an imperative to incorporate tools in general and specifically in education to encourage and build attitudes based on the exchange of values, mutual respect and reciprocal learning. We cannot forget that multiculturalism refers to a situation of diversity and cultural pluralism, often present in countries today due to migratory flows and new changes in contemporary society. Obviously, all these new stages lead to various conflicts and require a process of adaptation (Benet-Martínez and Nguyen, 2007).

This, then, is the importance of intercultural education, which must be based on three main pillars:

1. Training teachers. It is imperative to deal with diversity.

2. Programs for the integration of immigrant families (Jiménez, 2006).

3. Specific tools (linguistic adaptation, orientation for groups, teachers and parents; activities to promote values of interculturalism, such as respect and empathy; and to overcome significant barriers such as prejudices; to promote cooperation and acceptance of diversity).

But we must, in turn, also take into consideration the term we have attempted to explain; transculturation. A transcultural point of view reaches farther. It implies acceptance by different cultures that are in contact, not just over time, but in the present. Living together means acceptance and exchange of different values on an equal footing. Hybridization processes that took place in the past, survival responses to pressure from a powerful people characterized by mestizaje and adaptation to a new cultural reality (Trigo, 2000) can also take place in the future, because it is a reality present in one way or another in many countries or regions where different cultural and groups live together. However, there is a vital difference in the present day; this process can take place much faster due to rapid movement of the population because of immigration and other factors. What took centuries in the past has turned into a swift, unseen 
process. We have to take into account the increase of migration and the large number of cultures living together transculturally and influencing each other.

\section{Degrees of Transculturation in Multicultural Societies}

We have to take into account two different aspects. Although they are linked, it is important to distinguish modes from degrees of transculturation. We can identify three different modes:

\subsection{Direct transculturation.}

This takes place in countries that have suffered from cultural invasion. It also occurs in contexts of diversity where one of the cultures takes priority mainly due to its external superiority (economic, social or political). The dominant culture imposes its own criteria and tries strongly or insistently to diffuse the previous identity. As a result, a new cultural reality arises which is based mainly on the stronger culture, although there are traces of the subjugated minority group.

\subsection{Oblique transculturation.}

This can be considered indirect transculturation. When different cultures or traditions inhabit the same territory, there are unavoidable mutual cultural interchanges. Each group takes in elements of the others. This often takes place in contexts of immigration.

\subsection{Inverse transculturation.}

In some situations, the transculturation process develops in an unexpected direction because the minority group, in spite of pressure, transfers elements to the majority group, either by adaptation processes, or in order to discard its own values. This situation does not usually happen because of respect or similar motivations, but as a response to social needs. It is common in majority indigenous societies or in contexts where immigrants extrapolate their own elements to the host culture.

As mentioned above, the other aspect of transculturation is degree.

\begin{tabular}{|c|c|c|}
\hline \multicolumn{2}{|c|}{ Degree of transculturation } & \multirow{2}{*}{$\begin{array}{l}\text { Characteristics } \\
\text { Conservation of original culture } \\
\text { in a different hostile context. } \\
\text { Some aspects of the majority } \\
\text { group are taken on in order to } \\
\text { survive or as an adaptation } \\
\text { response. }\end{array}$} \\
\hline Low & Maintenance & \\
\hline & Partial maintenance & $\begin{array}{l}\text { Main aspects of own culture are } \\
\text { kept }\end{array}$ \\
\hline & Hybridization & $\begin{array}{l}\text { Traditional aspects wedded to } \\
\text { new elements,depending on } \\
\text { origin, family, peers or social } \\
\text { context }\end{array}$ \\
\hline & Assimilation & $\begin{array}{l}\text { New cultural reality. } \\
\text { Maintenance of slightly original } \\
\text { aspects in combination with new } \\
\text { culture. Typically second- } \\
\text { generation immigrants }\end{array}$ \\
\hline High & $\begin{array}{l}\text { Loss of original culture } \\
\text { (Total assimilation) }\end{array}$ & $\begin{array}{l}\text { After perceiving othemess as } \\
\text { superior, there is a radical } \\
\text { change which consists of } \\
\text { assimilating the extermal identity } \\
\text { with some aspects of the } \\
\text { previous identity but almost } \\
\text { completely diffused }\end{array}$ \\
\hline
\end{tabular}

Figure 1. Degrees of transculturation

Source: Prepared by author 
Transculturation occurs when there is contact between two different cultures and one of them directly or indirectly tries to impose its own standard. Consequently, there is a relationship between $\mathbf{A}$ (original culture) and $\mathbf{B}$ (external culture). In the past, the real contact was usually carried out by imposition and force, and $\mathbf{A}$ was usually diluted by pressure from $\mathbf{B}$. In contrast, in today's globalized world, transculturation mechanisms are rather different. B can take part in the activities of society, but can also keep a part of its tradition in private or family contexts. This can be considered biculturalism when there is perfect knowledge of both cultures and appropriate adaptation to every context. It can be the best way to develop one's own personality in a context of duality (Laframboise, Coleman and Gerton, 1993). Alternating between cultures can cause conflict, but it is unavoidable in multicultural contexts.

In predominantly indigenous societies, marginalization and exclusion often operate from $\mathbf{B}$ to $\mathbf{A}$. One important mechanism of transculturation in this direction is self-marginalization. Belonging to a cultural tradition implies exclusion. Due to this fact, and also because their traditions are really deep-rooted, especially in women, these collectives tend to keep their beliefs, practices, dress and idiosyncrasies, taking only parts of the imposed culture, and these only for social purposes. This situation is some what common in European and North American societies due to immigration, and exercised exclusively by particular groups, where it is a challenge in educational institutions.

\section{Conclusions}

Transculturation is an avoidable process in the meeting of different cultures. This fact is crucially important in today's society, where immigration flows and diverse societies are common. These processes, vital in past centuries because of historical causes, are frequent, prevalent and rapidly occurring in our globalized world. There are different modes and degrees of transculturation in society that depend on the survival, prevalence, imposition or generation of new cultural elements. These processes are even more powerful than the colonialism of the past, and they emerge as a consequence of globalization. In any case, although a part of the host culture can diminish or be diffused due to the pressure of many exogenous or endogenous factors, it can be also interpreted as a chance for the development of broad mindedness, tolerance, mutual consideration and understanding, and learning as well. The full set of the aspects examined here on imply a challenge for educators, schools, and for the general society as well. Nevertheless, we can encounter several difficulties in multicultural societies; "the rights of all individuals must be given equal consideration" (Giddy, 2011). This perspective could contribute to understanding transculturation in a positive way and as an effective tool. With respect to education, transcultural education is a response to new social needs. This circumstance emerges and becomes a factor in contexts where groups of people withalternative traditions, customs, habits of communication, and modes of cultural transmission come together.

\section{References}

Benet-Martínez, V. Nguyen, A. M. (2007). Biculturalism unpacked: Components, individual differences, measurement, and outcomes. Social and Personality Psychology Compass, 1, 101-14.

Berry, J.W. (1997). Immigration, acculturation, and adaptation. Applied Psychology: An International Review, 46, 5-34.

Cornejo Polar, A. (1994). Escribir en el aire. Ensayo sobre la heterogeneidad sociocultural en las literaturas andinas. Lima: Horizonte.

Giddy, P. (2012). More than tolerance: ethics for a multicultural society. Synthesis Philosophica, 54, 363-376.

Jiménez, A. (2006). Capítulo III. Programa para la integración de padres inmigrantes en entornos educativos. In Pantoja, A. and Campoy, T.J. (coords.), Programas de intervención en educación intercultural (pp. 81-110). Grupo Editorial Universitario.

LaFramboise, T., Coleman H., Gerton, J. (1993). Psychological impact of biculturalism: Evidence and theory, Psychological Bulletin, 114, 395-412.

Mazeau de Fonseca, P. (2004). Relación y transculturación como patrimonio cultural. Algunos apuntes comparativos entre la obra de Fernando Ortiz y la de Edouard Glissant. Segunda Etapa, 10, 191-206.

Muyolema-Calle, F. (2007). Colonialismo y Representación. Hacia una re-lectura del latinoamericanismo, del indigenismo y de los discursos etnia-clase en los andes del siglo XX. Unpublished doctoral dissertation. Universidad de Pittsburgh.

Ortiz, F. (1940). Contrapunteo cubano del tabaco y el azúcar. Havana: J. Montero.

Rama, A. (1974) Sistema literario y sistema social en Hispanoamérica. Literatura y praxis en América Latina. Caracas: Monte Avila.

Trigo, A. (2000). Shifting Paradigms: From Transculturation to Hybridity: A Theoretical Critique. In De Grandis, R., Bernd, Z. (2000). Unforeseeable Americas: Questioning Cultural Hybridity in the Americas. Atlanta: Editions Rodopi. 